aurora flashes, though it does not seem to have been remarked. My own observations have all been made with a very wide slit, or, which comes practically to the same thing, with small dispersion. This has been owing to the usual feebleness of the greater part of the spectrum; and many of the other observers have for the same reason also used a wide slit. It may be useful to explain the method by which most of my observations were made, as it seems successful for perceiving the lines and general character of the spectrum, though not for measuring the positions. I have simply used one or two, or in some cases three prisms, usually of Chance's dense flint glass, and for a slit, the space between window-shutters nearly shut, or between two planks placed against the window. I hold the prisms in my hand on a simple stand, not always fixed, but so that they may be easily moved with respect to each other and to the slit, so varying the amount of dispersion. The best results are usually obtained by holding them in the position of almost the greatest deviation possible. Varying the deviation alters the focus. If one plank or shutter is placed rather further forward than the other, the apparent width of the slit is varied at will by simply moving one's head to one side or the other. By these means it is easy to observe all the different features of the spectrum, which require different widths of the slit and degrees of dispersion. A vacuum-tube or other light for comparison may be placed behind the slit, though it is obvious that with small dispersion accurate comparisons cannot be made.

I have made some observations with a Browning's " Miniature Spectroscope," with the diaphragm off, but it gives less light than simple prisms. I have also tried a "half-prism spectroscope," by Hilger, but unsuccessfully; but I find that by taking off the outer lens of the eyepiece and the diaphragm much more light is obtained; I have not, however, had an opportunity of trying this plan yet on an aurora.

The number of nights of aurora on which I have seen each line, between 1871, November I, and I883, March 27, is as follows :-

$$
\begin{array}{ccccccc}
\beta & \alpha & \epsilon & \zeta & \eta & \gamma & \delta \\
\text { II } & 83 & 34 & \text { I4 } & 7 & 33 & 26
\end{array}
$$

On thirteen nights I could not be sure of any line, but on six of these I suspected $\alpha$, or else there was an abrupt fading away about where $a$ should come. There were other auroras -mostly faint ones-whose spectra I did not observe.

The lines visible in the spectrum often vary in the course of a few minutes, and indeed are not always the same in different parts of the sky at the same time. I have never been able to detect that any particular feature of the spectrum belongs to any particular type or feature of aurora, except that the line $\beta$ belongs to red auroras.

Dr. Vogel thinks it probable that the auroral spectrum is a modified air-spectrum. The following are the most striking coincidences or approximations between my revised list of auroral lines and Vogel's lists of lines in the spectra of air and its constituents. They are sufficient to make the subject one worthy of consideration; but perhaps this is as much as can as yet be said. There are other approximations to very $f_{d i n t}$ air or gas lines, which he regards as of some importance; but, as the lines in the latter spectra are so numerons, one would naturally expect such coincidences accidentally.

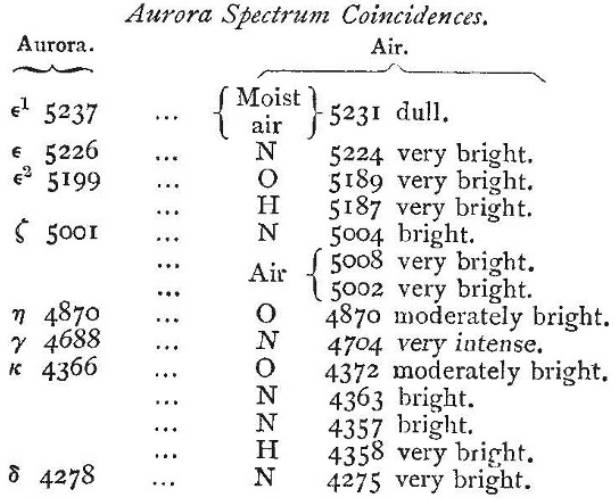

A. S. Herschel has pointed out the proximity of $\beta$ to the dark atmospheric band $\alpha$ at 6279 .

Sunderland

\section{SCIENCE AT KAZAN}

THE Kazan Society of Naturalists, which began its Memoirs in I87 I with the remarkable work of $M$. M. Bogdanoff on the birds and mammals of the black earth region of the basin of the Volga, has continued since to publish a series of most valuable explorations of the region of the lower Ural, Volga, and Siberia. We notice thus in the first eight volumes of its Memoirs the researches on earthquakes in Siberia, in Turkestan, and on the Ural, by M. Orloff; several valuable papers on the Geology of the Obschiy Syrt plateau, by M. Sintsoff; of the Government of Vyatka, by M. Krotoff; of the Government of Kazan, by Prof. Stuckenberg; and of the banks of the Kania, by M. Zaitseff; a work on the birds of Caucasus, by M. Bogdanoff; a paper on the Teleostei of the mouth of the Volga, by M. Yakovleff; the history of the development of the Acipenser sturio, by M. Zalensky; and mycological researches, by $M$. Sorokin; several papers on the flora of the Government of Perm, by M. Kryloff; and two papers by M. Levakovsky on the substitution of certain species of plants for others in a given region; as well as several valuable researches into the anthropology of the Bashkirs, Voguls, and Votyaks, by MM. Malieff, Sorokin, and Ostrovsky.

The three last volumes of the Memoirs, which ne have now before us, contain also many valuable papers. In the depart. ment of botany we notice the second part of M. Kryloft's flora of the Government of Perm. It contains a complete list of all Phanerogame discovered in this interesting province, which includes the Ural Mountains, completed by special researches into the subarctic and Alpine flora of this region. A map shoxs pretty well how such plants as the Viburnus opulus, the Cystisus biflorus, the Tilia parviflora, and the cereals are stopped in their extension by the Ural Mountains, reappearing again on their eastern slope; whilst others, like the Ouercus pedunculata, or the Acer platanoides, are stopped in their extension towards the east by the western spurs of the Ural and the lowlands of Siberia, their north-eastern limit meeting nearly together with the south-western limit of extension of the Pinus cembra, the Lonicera carulea, the Spirce media, and Polygonum viviparum. The whole list contains 948 Angiospermæ, and 8 Gymnospermx. The Cryptogamæ are represented by 38 Lycopodiacex and 124 Lichens.-Dr. Martianoff publishes valuable materials for the flora of the Minusinsk region in Eastern Siberia, comprising a sketch of its climate (according to five years' meteorological observations by A. Krapotkin) and its physico-geographical characters. The flora of Minusinsk is much varied, as it e nbodies three separate botanical regions: the Alpine, the forest, and the steppe floras, intermingled with one another. Its general character is that of the Altai region, and out of 777 Phanerogams, no less than $7 \times 4$ are Altaic, whilst only 59 belong to the flora of Eastern Asia. The Alpine flora has but IO4 $_{4}$ representatives; the forest-flora is the most widely spread, and at the same time the richest; it is represented by 579 species. The steppe $\mathrm{fl} \mathrm{ra}$, which covers nearly one-quarter of the Minusinsk district, and appears sporadically even on the plateaux of the hilly tracts, numbers $3 \mathrm{I} 5$ species. We can only notice here the excellent botanical sketches of separate parts of this "Siberian Italy" which we find in M. Martianoff's work. His list of plants, which contains 760 species of vascular plants, is unusually rich also in lower plants, the number of determined Fungi and Myxomycetes comprising 644 species.-An interesting work which has cost much labour to its author, M. Kryloff, is a description of all drugs-mostly plants-used in the popular pharmacies of the Governments of Kazan and Perm. The list comprises abnut 200 plants, with a description of their use in popular medicine.

The zoological papers in this volume are but two:-On the innervation of the heart of the Esox lucius and Acipenser ruthemus, by MM. Kazem-beck and Doguel; and on the ear-labyrinth of the Plagiostomi (Acipenser ruthenus, A. sturio, and A. schiffa), by M. Sizoff, Both papers have appeared also in the Archiv fïr microskopische Anatomie.

Geology is represented by the following papers:-On the upper part of the mottled marls, by Prof. Stuckenberg; on the Permian in the Governments of Kazan and Samara, by A. Zaitseff; and on the geology of the Volga between Nijni-Novgorod and Kazan, by P. Krotoff. The Zechstein appears in the region situated between the Kama, the waterix., x., and xi., $2880-1882$. 
shed of the Sok and Sheshma, and the Volga, as an island extending from north-east to south-west, and covered on its borders by mottled marls. The former is closely mingled with the latter, as it extends also in the shape of thinner intermediate deposits among the marls; but on the whole it substantially differs from them by its fauna, undoubtedly belonging to the Zechstein. As to the mottled marls, they contain the Unio umbonatus, Fisch., the Estheria sp. (Posydonomia minuta, Brunn.), the Lingula orientalis, Golowkinsky, scales of Acrolepis macroderma, Eichw., and Calamites. The Post-Pliocene deposits are spread everywhere, and we notice the find of Caspian shells of Cardium, together with Dreissena, at the sources of the Cheremshan river (left tributary of the Volga, namely, at Balandino, ten miles from the Cheremshanskaya fort). This important find proves thus that the Caspian formerly extended at least as far north as $54^{\circ} 40^{\prime}$ north latitude. As to the Permian formation to the west of Kazan, M. Krotoff, who includes in this formation both the Zechstein and the mottled marls, calculates that it has a thickness of 8 ro to 860 feet. Showing further that the fauna of the mottled marls but slightly differs from that of the Zechstein (a complete list of its fossils being given by the author), and that the fossils that are characteristic of these marls (Unio umbonatus, Fisch., Unio castor, Eichw., Estherio sp., Cythere sp., remains of fishes, and Calamites) were found elsewhere, either in company with purely Zechstein forms or in deposits subordinate to the Zechstein deposits, he concludesperhaps too soon-that there is no ground to consider them as Triassic.

Anthropology and archæology are represented by several interesting papers:- - . Krotoff publishes his researches into the age of the stone implements found in the basin of the Oka, and M. Ivanoff on the Perm region.-M. Malieff publishes the results of his most interesting measurements of the Old Bulgarian skulls dug out from the Babiy Bugor, at the Bulgarian village situated on the left bank of the Volga, close to Tetushi, and his paper is accompanied by sixteen photographs of four skulls. He measured the best preserved twenty-five skulls, all belonging to full-grown males. They are all much like one another, but could be subdivided into three groups : fourteen dolichocephalic, with indexes varying from $7 \mathbf{I}^{\circ} 4$ to $77^{\circ} \mathbf{I}$; five mesatycephalic, their indexes varying from 77.8 to 79.8 ; and five subbrachicephalic, whose indexes vary from $8 x^{\circ} \cdot$ to $82 \cdot I$. The average size of the horizontal circumference of the twenty-five skulls is 5I 5 millimetres, with a maximum of 555 millimetres and a minimum of 490 ; the average capacity is $138 \mathrm{r}$ cubic centimetres. They completely differ from the skulls of other inhabitants of the same region: not only Kalmuks, or Bashkirs, but also from the Russian, Tartar, or Mordovian skulls. Without expressing a definitive opinion until a comparison of these skulls with those of Bulgarians from the Balkan peninsula is made, the author points out that they are very much like those of the Kuorgan inhabitants of the Government of Moscow, who seem to be Old Sclavonic, and certainly are not Finnish, as results from an inquiry made on 120 skulls by Prof. A. Bogdanoff. They are similar also to the skulls of the old inhabitants of Kieff and to those of the Scythes of Southern Russia. M. Malieff's companion in these researches, who gives in the same periodical a sketch of the Old Bulgarian burying-place at Babiy Bugor, adds that the skeletons they dug out had their heads towards the west, and were lying on the left side, looking towards the north (towards the Volga). Masses of pieces of earthenware were found together with the skeletons, and the pottery was of the roughest kind, made by hand, and burned very incompletely. $\mathrm{He}$ argues with much probability that this burying-place did not belong to a Mussulman people, but to idolaters, and supposes that its antiquity may be traced as far back as the Stone period. In any case, the customs of burying, as shown by this buryingplace, seem to have been very much like those of the Sclavonians before their conversion. As to the burying-places at Chulpanovka and Ukrech, in the districts of Christopol and Laisher, explored by MM. Malieff and Vysotsky and described by the latter in his second "Anthropological Sketch of the Explorations of the Year 1880," and by M. Malieff in his just-mentioned paper, both explorers agree in considering them as belonging to Chuvashes. The craniological measurements which M. Malieff made on twenty skulls show that six of them belong to the mesatycephalic type, the average cephalic index of which is $74^{\prime} 5$, and the others are either dolichocephalic, or belong to women and children, or afford a most pronounced asymmetry, and cannot thus give reliable figures.

\section{UNIVERSITY AND EDUCATIONAL} INTELLIGENCE

THE alumni and other friends of the University of St. Andrews have been roused to action by the threat (now withdrawn) of its possible dissolution, in consequence of insufficient endowment. An "Appeal" which has just been issued shows that $2700 l$. (in sums of from $100 l$. to $1000 l$.) has been already subscribed towards the better endowment of the Professorial Chairs ; and a scheme has been set on foot amongst the younger graduates for the no less essential object of securing the augmentation of the open bursaries. Upwards of $2 \mathrm{col}$. (in sums of from $\mathrm{Il}$. to $50 \mathrm{l}$ ) ) has been already promised towards this special fund, and an appeal from the Committee appointed for this purpose will shortly be circulated. There is good reason to believe that the withdrawal of the obnoxious clause has been partly occasioned by the practical shape which the defence of the oldest Scottish University has thus assumed.

\section{SCIENTIFIC SERIALS}

The American Fournal of Science, June, I883. - On the nature of the induration in the St. Peter's and Potsdam sandstones and in certain Archæan quartzites, in Wisconsin, by R. D. Irving. The author extends the conclusions already arrived at by Sorby in several important respects. - On the existence of a deposit in NorthEastern Montana and North-Western Dakota, that is possibly equivalent with the Green River group, by Charles A. White. The paper embodies a detailed description of the new extinct genus and species of Percidæ occurring in the Dakota rocks, by Prof. E. D. Cope.-On the peculiar concretions occurring in meteoric irons, by J. Lawrence Smith. These concretions are found to contain sulphuret of iron, schreibersite (phosphuret of iron and nickel), graphite, daubréelite, chromite, lawrencite, aragonite.-On mineral vein formation now in progress at Steamboat Springs compared with the same at Sulphur Bank, by Joseph Le Conte.-Observations on the transit of Venus, Uecember 6, 1882, at the Vanderbilt University Observatory, Nashville, Tennessee, by Olin H. Landreth.-On the fauna found at Lime Creek, Iowa, and its relation to other geological fauna, by S. Calvin. A complete catalogue is given of the Lime Creek fauna which are compared with those of the Niagara, Cinderhook, and other Devonian rocks.-Observations on stratified drift in Delaware, by F. D. Chester. - On the western discharge of the flooded Connecticut, or that through the Farmington Valley to New Haven Bay, by James D. Dana.-Results of some experiments made to determine the variations in length of certain bars at the temperature of melting ice, by R. S. Woodward, E. S. Wheeler, A. R. Flint, and W. Voigt. The experiments are chiefly made with zinc and steel bars, and the authors found that zinc is the least reliable metal for the components of a metallic thermometer and standard of length, while steel, copper, and brass do not vary appreciably at any ordinary temperature.-On Scovillite, a new phosphate of didymium, yttrium, and other rare earths, from Salisbury, Connecticut, by George J. Brush and Samuel L. Penfield.

Fournal of the Royal Microscopical Society for April, 1883, contains :- On five new Floscules, with a note on Prof. Leidy's genera, Acyclus and Dictyophora, by Dr. C. T. Hudson (Plates 3 and 4).-The President's (Prof, P. M. Duncan) address. - The action of tannin on the cilia of Infusoria, with remarks on the use of a solution of sulphurous oxide in alcohol, by $\mathrm{H}$. J. Waddington.-Summary of recent literature.-Proceedings of the Society.

Journal of the Russian Chemical and Physical Society, vol. xv. fasc. 4.-On solutions, by W. Alexeyeff; being an inquiry into the mutual solutions of liquids, as depending upon temperature. The experiments carried out on aniline, amyl and isobutyl alcohols, phenol, \&c., lead to the following conclusions :- -The liypothesis of Person as to the liquefaction of bodies before solution is not confirmed. The solubility depends upon the molecular cohesion, and increases as this last becomes feebler. Thus, at the same temperature, more of liquid than of solid salicylic acid is dissolved. The solutions are quite different from chemical compounds, and the liquid mixtures are different from solutions. - On the specific volumes of elements in liquid compounds; second paper, by M. Shalfeyeff. The conclusions of these valuable researches are:-The compounds of the fat series are derived from the uneven-atomic carbon; and those of the 